\title{
Ecological forestry at National Wildlife Refuges: Experiences from Seney National Wildlife Refuge and Kirtland's Warbler Wildlife Management Area, USA
}

\author{
by R. Gregory Corace, III ${ }^{1,2}$, P. Charles Goebel ${ }^{3}$, David M. Hix ${ }^{4}$, Tracy Casselman ${ }^{1}$ and Nancy E. Seefelt ${ }^{5}$
}

\begin{abstract}
Although land management over much of the history of the U.S. Fish and Wildlife Service's National Wildlife Refuge System (NWRS) has emphasized single-species management, recent policy has encouraged land managers to focus on broader ecosystem restoration goals. One framework for forest ecosystem management that is becoming more popular in the NWRS and other federal and state resource agencies has been termed "ecological forestry" - an approach to forest ecosystem management where the focus is on incorporating an understanding of the outcomes of natural disturbances and stand development processes into designing silvicultural practices. This approach stresses understanding the effects of natural disturbances on biological legacies, structural and compositional heterogeneity, and the recovery periods between disturbance events (including how this recovery period influences stand complexity). Recently, resource managers and ecologists from Seney National Wildlife Refuge, The Ohio State University, and Central Michigan University have partnered to examine how these guiding principles can be integrated into NWRS forest ecosystem management. Specifically, we are partnering to develop management strategies to help: 1) restore the once extensive mixed-pine forest ecosystems of eastern Upper Michigan; 2) mitigate the effects of the beech-bark disease complex on American beech (Fagus grandifolia Ehrh.), a foundation species in northern hardwood forests of eastern North America; and 3) promote more natural forest patterns for wildlife species of young jack pine (Pinus banksiana Lamb.) forest ecosystems, including the federally endangered Kirtland's warbler (Dendroica kirtlandii). These efforts are ongoing and will continue to be monitored over time. However, initial collaborations suggest that the NWRS provides an excellent crucible to study the application of ecological forestry principles and develop novel ways to manage forest ecosystems.
\end{abstract}

Key words: ecological forestry, forest restoration, Kirtland's warbler, National Wildlife Refuge, U.S. Fish and Wildlife Service

\section{RÉSUMÉ}

Même si l'aménagement du territoire au cours de la majeure partie de l'histoire du Réseau national de réserves fauniques (RNRF) du U.S. Fish and Wildlife Service a porté sur l'aménagement en fonction d’espèces individuelles, les récentes politiques ont encouragé les aménagistes à tenir compte d’objectifs plus étendus lors de la restauration d'un écosystème. Un cadre de référence relié à l'aménagement des écosystèmes forestiers de plus en plus populaire au sein du RNRF et d’autres agences fédérales et étatiques de gestion des ressources, a été intitulé « foresterie écologique » - une approche en matière d’aménagement des écosystèmes forestiers portant sur l'intégration et la compréhension des effets des perturbations et des processus naturels de développement des peuplements dans les pratiques sylvicoles. Cette approche nécessite la compréhension des effets des perturbations naturelles relativement aux retombées biologiques, à l'hétérogénéité de la structure et de la composition et aux périodes de récupération entre les événements perturbateurs (incluant linfluence exercée par cette période de récupération sur la complexité du peuplement). Dernièrement, les aménagistes et les écologistes de la Réserve faunique nationale de Seney, de l'Ohio State University et du Central Michigan University se sont regroupés pour étudier comment ces principes directeurs pouvaient être intégrés dans l'aménagement des écosystèmes forestiers du RNRF. De façon plus précise, nous avons créé un partenariat pour élaborer des stratégies pour aider : 1) à restaurer les anciens écosystèmes de peuplements mélangés de pin de l'est de l'Upper Michigan; 2) à atténuer les effets de la maladie corticale du hêtre (Fagus grandifolia Ehrh.), une espèce jouant un rôle déterminant dans les forêts des feuillus nordiques de l'est de l'Amérique du Nord et, 3) à promouvoir des patrons forestiers plus naturels aux yeux des espèces fauniques dans les jeunes écosystèmes forestiers de pin gris (Pinus banksiana Lamb.), incluant la fauvette de Kirtland (Dendroica kirtlandii), une espèce en péril à léchelle nationale. Ces efforts sont soutenus et continueront dêtre évalués dans le temps. Cependant, la collaboration initiale laisse entendre que le RNRF constitue un excellent creuset pour l'étude de l'application des principes de la foresterie écologique et le développement de nouvelles façons d’aménager les écosystèmes forestiers.

Mots clés : foresterie écologique, restauration forestière, fauvette de Kirktland, Refuge faunique national, U.S. Fish and Wildlife Service

\footnotetext{
${ }^{1}$ U.S. Fish and Wildlife Service, Seney National Wildlife Refuge, 1674 Refuge Entrance Rd., Seney, MI 49883, USA.

${ }^{2}$ Corresponding author. E-mail: Greg_Corace@fws.gov

${ }^{3}$ School of Environment and Natural Resources, The Ohio State University, 1680 Madison Ave., Wooster, OH 44691, USA.

${ }^{4}$ School of Environment and Natural Resources, The Ohio State University, 2021 Coffey Rd., Columbus, OH 43210, USA.

${ }^{5}$ Department of Biology, Central Michigan University, Mt. Pleasant, MI 48859, USA.
} 


\section{Introduction}

Established in 1903 with the creation of the Pelican Island Wildlife Refuge in Florida by President Theodore Roosevelt, the U.S. Fish and Wildlife Service's National Wildlife Refuge System (NWRS) now consists of more than 547 refuges and 39 million ha (95 million ac). Although land management over much of the history of the NWRS has emphasized management for migratory birds, recent legislation (i.e., Refuge Improvement Act of 1997) and policy (i.e., Biological Integrity Policy of 2001) has encouraged a broader, more inclusive focus for NWRS land management that encompasses all existing cover types, while still addressing the needs of U.S. Fish and Wildlife Trust Resources (Karr 2004, Scott et al. 2004). Both call for refuge managers to favour ecologically based land management practices, with restoration to preEuropean conditions where and when possible (Schroeder et al. 2004, Meretsky et al. 2006). These documents also provide the basis for the broad-scale application of ecological forestry principles (Seymour and Hunter 1999, Franklin et al. 2007). Of 92 Midwestern and Northeastern refuges and other stations that recently responded to a survey regarding the value of forest management, $70 \%$ deemed forest management an important present-day aspect of refuge habitat management: $56 \%$ stated that the goal of forest management at their refuge was to promote ecological integrity, while $37 \%$ identified focal species habitat as the primary focus of forest management (USFWS 2006).

We present 3 examples of how the guiding principles that characterize ecological forestry, as recently suggested by Franklin et al. (2007), can be integrated into the management of forest ecosystems. Two examples come from Seney National Wildlife Refuge (SNWR) in Michigan's eastern Upper Peninsula and another comes from Kirtland's Warbler Wildlife Management Area (KWWMA) in the northern Lower Peninsula. In particular, using the "3-legged stool" concept of ecological forestry proposed by Franklin et al. (2007), we focus our review on how managers at these 2 NWRS units are working to: 1) incorporate a better understanding of the biological legacies created by natural disturbances and by harvesting treatments; 2) develop a deeper understanding of how forest stand development processes help create stand structural and compositional heterogeneity that can be emulated with silvicultural prescriptions; and 3) appreciate the role of recovery periods between disturbances and how this affects both stand and landscape complexity. The specific examples include mixed-pine forest ecosystem restoration, mitigating the effects of beech bark disease, and promoting wildlife habitat conditions (including that for the federally endangered Kirtland's warbler (Dendroica kirtlandii Baird) that better emulated natural structural patterns in early successional jack pine (Pinus banksiana Lamb.) ecosystems.

\section{Historical Management at SNWR}

At 38544 ha (95 $245 \mathrm{ac}$ ), SNWR is one of the largest refuges east of the Mississippi River. From the perspective of a forest manager, SNWR has the positive features of being within a forested matrix of state, federal, and corporate ownership, having most pre-European settlement cover types still present, having few non-native invasive species, and having a relatively low population of the main browser of woody plants, white-tailed deer (Odocoileus virginianus Zimmermann). To maintain the current assemblage of forest cover types and flora and fauna, forest management at SWNR conserves, rehabilitates, and restores nationally, regionally, or locally imperilled forest ecosystems and habitat types. These goals take into account the value of both anthropogenic and natural habitats, and the importance of natural patterns and processes.

Forest ecosystems at SNWR have experienced periods of different land-use practices, starting in the mid-1800s (Karamanski 1989, Verme 1996, Dickmann and Leefers 2003). Following settlement by Europeans, stands of red pine (Pinus resinosa Ait.) and eastern white pine (P. strobus L.) that were accessible either by road or stream were altered from their original conditions by exploitive logging and the resulting wildfires fuelled by logging debris (Karamanski 1989, Verme 1996, Drobyshev et al. 2008a, b). As the amount of available saw-timber diminished, harvesting shifted to cutting of poles, posts, ties, and pulp-wood (Verme 1996). Subsequent farming communities on these lands (Losey 2003) were then hampered by imperfect drainage of peat soils, poor soil fertility, and a short growing season. In 1935, Seney Migratory Waterfowl Refuge (later re-named) was established by Executive Order under the Migratory Bird Conservation Act of 1918 for the protection and production of migratory birds and other wildlife (Losey 2003). Early management of SNWR forests focused on removing trees to create water impoundments for waterfowl production or to maintain habitat for game species of early successional forest ecosystems (e.g., sharp-tailed grouse, Tympanuchus phasianellus L.; ruffed grouse, Bonasa umbellus L.; white-tailed deer) (Johnson 1947, Rist 2008).

In more recent times, forest management has become more ecologically based and de-emphasizes single-species objectives (Simberloff 1997). Planning and management has increasingly taken into account succession pathways dictated by soil types (Burger and Kotar 2003) and perspectives of landscape (Forman 1995, Askins 2000) and disturbance ecology (Frelich 2002) within a wildlife conservation context (Hunter 1990). Management objectives shifted to conserving the diversity of forest and non-forest cover types and seral stages at the landscape scale, while providing ecosystems and seral stages important for wildlife species of national, regional, state, or local conservation priority. At the patch scale, management conserves and restores historic forest composition and structure, while increasing mean patch size and connectivity between similar forest types (Crozier and Niemi 2003). For instance, early successional forests of quaking aspen (Populus tremuloides Michx.) and jack pine that now exist along the boundaries of SNWR are being retained and linked with adjacent even-aged forest stands managed by the State of Michigan.

\section{Restoration of Mixed-pine Forests at SNWR}

Historically, most of the upland soils at SNWR supported a mixed-pine forest ecosystem of red pine and eastern white pine, and to a lesser degree jack pine (Burger and Kotar 2003). These mixed-pine forests existed in a landscape of glacial outwash channels, and sand ridges interspersed within a matrix of lowland swamp forests and string bogs (Heinselman 1965, Comer et al. 1995). This mixed-pine forest type was also more broadly characteristic of the eastern Upper Peninsula and comprised approximately $38 \%$ of the pre-European settle- 


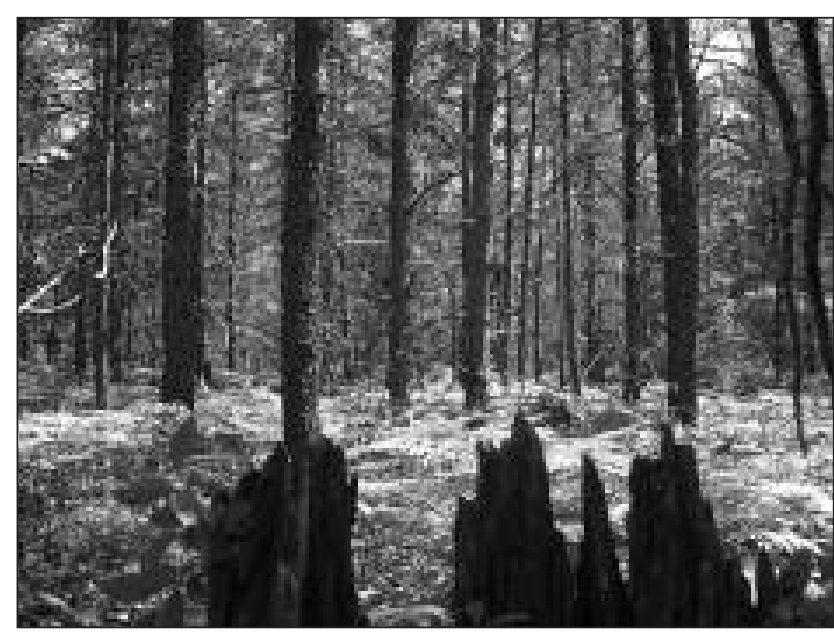

Fig. 1. Jack pine stand with large-diameter eastern white pine stump in foreground, Seney National Wildlife Refuge.

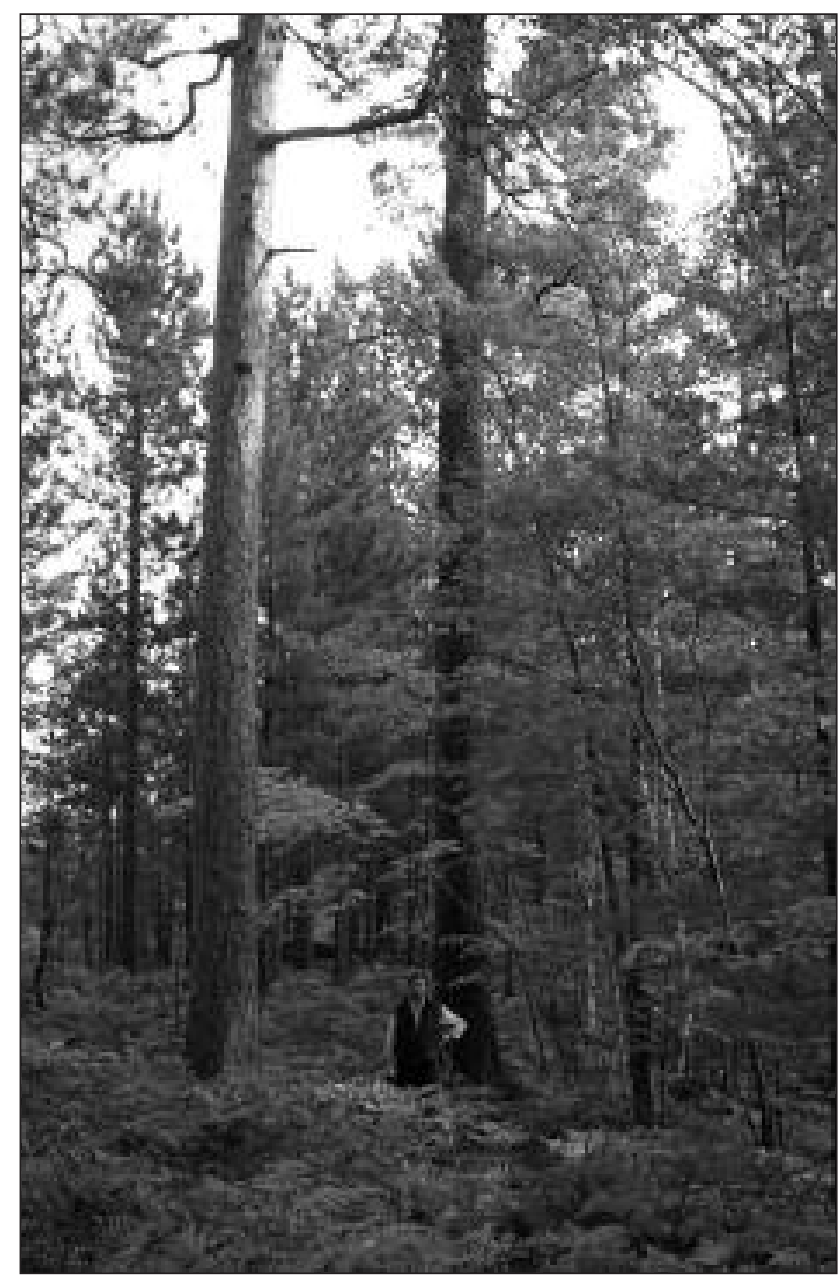

Fig. 2. Old-growth eastern white pine (center) and red pine (left] in the Seney Wilderness Area, Seney National Wildlife Refuge.

ment forests (Zhang et al. 2000). However, less than $1 \%$ of the primary red pine and eastern white forests exists and most of these forests have been structurally and compositionally altered due to past land-use actions (Drobyshev et al. 2008a, b; Fig. 1).

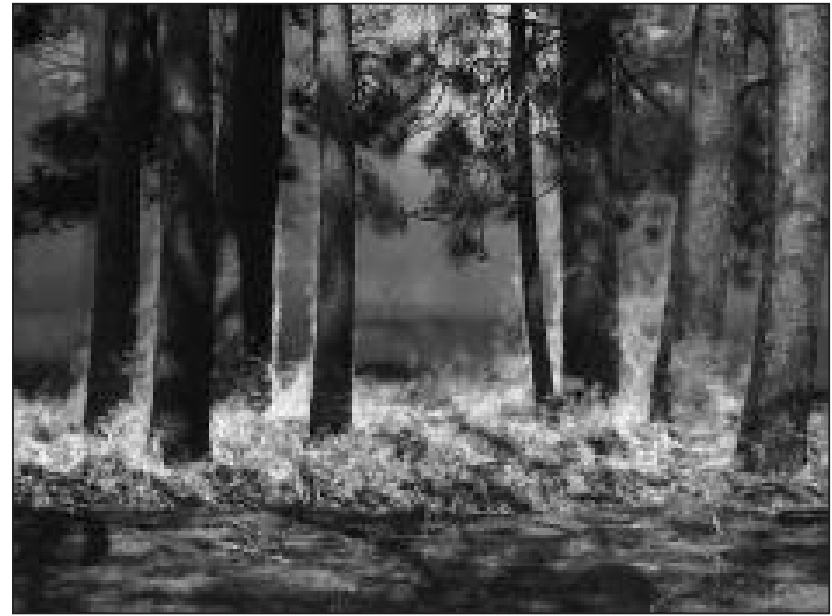

Fig. 3. Prescribed fire used in a red pine stand, Seney National Wildlife Refuge.

Recent research at SNWR has better characterized the disturbance regime associated with mixed-pine forests. Unlike other areas of the northern Lake States and adjacent Canada where stand-replacing fires dominated the pre-European settlement landscape (Heinselman 1973, Bergeron and Brisson 1990), we have found that frequent, non-stand replacing fires were more common at SNWR (Drobyshev et al. 2008a). These low-intensity surface fires usually created small gaps, or left the overstory trees unaltered while maintaining a relatively open understory (Fig. 2). Over time, these disturbances tended to produce mixed-pine stands with an uneven-aged structure and variable fuel loadings (Drobyshev et al. 2008b). However, past harvesting activities and other land-use practices have modified the fire regime considerably, as more intense and frequent fires dominated the post-European settlement and "Great Cutover" (Heinselman 1965) periods (1860-1935), while the post-Refuge establishment period (1935-present) has been characterized largely by the absence of fires. The results of these changes to the fire regime have been to markedly change the structure and composition of SNWR mixed-pine forests. When compared to the scattered old-growth mixed-pine forest ecosystems at SNWR, the second-growth mixed-pine forests that have developed over the past decades have much higher and more homogenous fuel loadings, increased dominance of fire-intolerant species (e.g., quaking aspen and red maple, Acer rubrum L.), less structural complexity, and less red pine and eastern white pine regeneration (Drobyshev et al. 2008b).

The patch-scale focus of mixed-pine forest restoration at SNWR has promoted greater ecological integrity by restoring the composition and structure in altered stands, and conserving or preserving these characteristics in relatively unaltered stands. In even-aged, more structurally monotypic stands at SNWR, an emphasis has been placed on creating components observed in old-growth stands that have experienced frequent, low-intensity surface fires (Fig. 3). For example, SNWR land managers seek to retain coarse woody debris and standing snags, with an emphasis on restoring the complex structure observed in the old-growth mixed-pine stands at SNWR. We know that the size, diversity, and abundance of snags may be the most important factors affecting bird diversity and abundance at the stand scale (Sallabanks and Arnett 

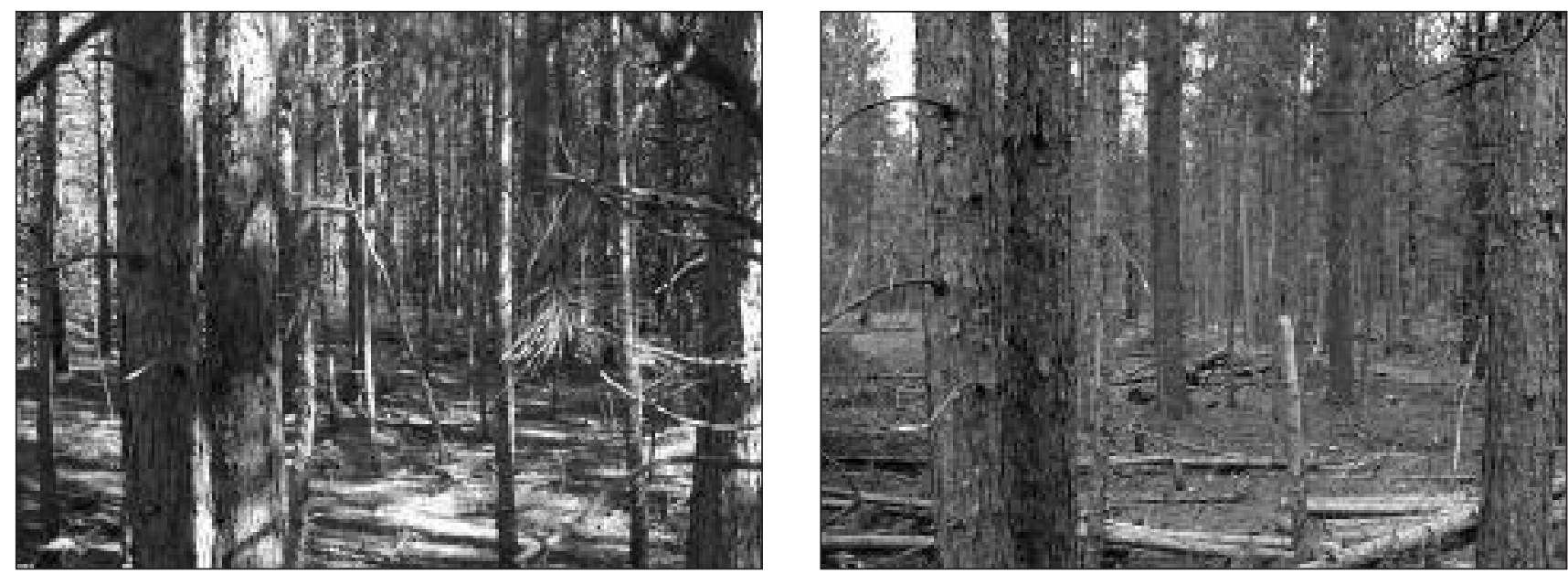

Fig. 4. Before (left) and after (right) views of a harvested pine stand managed to reduce fuels and restore mixed-pine forest ecosystem characteristics, Seney National Wildlife Refuge.

2005). Additionally, research conducted at SNWR indicates that stands with greater structural diversity (including more coarse woody debris and snags) also have more diverse small mammal communities, which are an important component of northern forest ecosystems (Harrington 2006).

With reference conditions provided by the detailed research on fire regimes and historic effects on forest structure and composition (Drobyshev et al. 2008a, b), SNWR managers are beginning to design regeneration methods that significantly decrease the dominance of jack pine, while increasing the reproduction and growth rates of red pine and eastern white pine. Such management will produce stands with characteristics more typical of the reference conditions. For example, in 2007 SNWR implemented a silvicultural system on $122 \mathrm{ha}(300 \mathrm{ac})$ to develop attributes of late-successional, mixed-pine forests in second-growth stands (Fig. 4). The patch clearcutting method was primarily used to create openings for red pine and eastern white pine establishment, primarily by harvesting all jack pine trees larger than $15 \mathrm{~cm}(6$ in) $\mathrm{DBH}$ and "reserving" red and eastern white pine trees in these areas. Elsewhere, significant red pine regeneration was thinned to increase growth rates of the crop trees. Increased stand heterogeneity and mechanical scarification of the soil, critical for red and eastern white pine germination and establishment-a process that Drobyshev et al. (2008b) indicated has been lacking in these stands-were accomplished by the use of tracked harvesters and dragging of tree tops. Moreover, efforts were made to retain all existing snags and 107 new snags were created by "girdling."

A common problem faced by many forest managers is convincing others of the need for mechanical treatments in the initial stages of restoring fire-dependent ecosystems (Fule et al. 2001). Often, fire has been considered the only tool for restoring fire-dependent ecosystems. Current research (Drobyshev et al. 2008a, b) suggests that to restore composition and structure of mixed-pine forest ecosystems at SNWR, fire is but one of the tools. Used too often or incorrectly (such as with the high fuel loadings in dense jack pine stands) fire may actually reduce the likelihood of meeting certain management objectives that are based on ecological restoration goals. Although SNWR has an active prescribed fire program

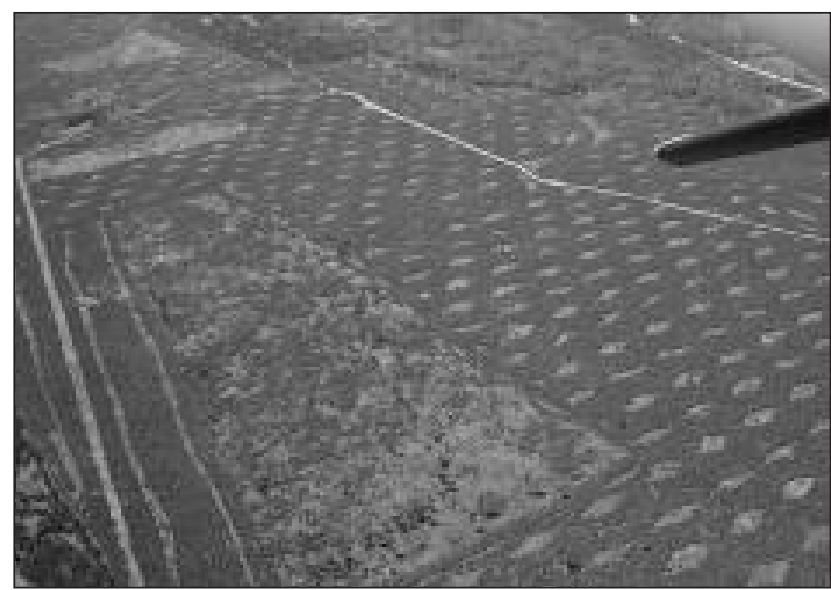

Fig. 5. Aerial view contrasting structural patterns resulting from 2 different jack pine stand regeneration treatments at Kirtland's Warbler Wildlife Management: prescribed fire (left) and plantation (right).

and a Fire Use Plan, fire management must continue to proceed within an ecological framework. Shifting stand dominance from jack pine to mixed-pine by using mechanical treatments first, and then following with prescribed fire after fuel loading has decreased, is expected to help meet goals of mixed-pine forest ecosystem restoration and fire safety.

\section{Conservation and Rehabilitation of Northern Hard- wood Forests at SNWR}

Whereas the mixed-pine forest ecosystem example discussed above illustrates (in part) the impacts of an altered ecosystem process (cessation of fire), management efforts in northern hardwood stands at SNWR focus on the conservation and rehabilitation of stands affected by a non-native disease complex. Beech bark disease, a complex involving a non-native scale insect, pathogenic fungi, and American beech (Fagus grandifolia Ehrh.), threatens the major mast-producing tree species in northern hardwood stands (Lovett et al. 2006). Beech bark disease may affect an entire food chain that is dependent upon beechnuts. 
Although the overall impact of beech bark disease is presently unknown (it is expected to cause mortality in many, but not all, large-diameter trees; Ostrofsky and McCormack 1986), the canopy gaps created by beech mortality have the potential to enhance stand composition by promoting midtolerant species such as yellow birch (Betula alleghaniensis Michx. f.) and the shade-tolerant and uncommon conifer, eastern hemlock (Tsuga canadensis L.). To avoid killing a potentially disease-resistant tree, no beech trees are being harvested, but rather a 3 -step process is proposed to enhance the species composition of northern hardwood stands: 1) yellow birch and eastern hemlock crop trees will receive crowntouching releases to promote seed production (Perkey and Wilkins 2001);2) the openings around dead or dying beech trees will be enlarged to create larger canopy gaps; and 3 ) the saplings that establish will be managed by hand-cutting to minimize maple dominance and favour yellow birch and eastern hemlock. These management strategies emulate the gap dynamics that are characteristic of SNWR northern hardwood stands, fostering the structural and composition heterogeneity found in reference stands of the region (Frelich 2002).

\section{Intensive Jack Pine Habitat Management at KWWMA}

Established in 1980 to aid the recovery of the federally endangered Kirtland's warbler, KWWMA consists of 125 tracts totalling nearly 2711 ha $(6700 \mathrm{ac})$ over 8 counties of the northern Lower Peninsula of Michigan. A ground-nesting, neotropical migrant, Kirtland's warbler breeds almost exclusively in young (5- to 23-year-old) jack pine growing in a dense and patchy stands (Probst 1986, Probst et al. 2003). Managed to provide breeding habitat for Kirtland's warbler in concert with adjacent state-owned forests, approximately $8 \%$ of the global breeding population of Kirtland's warbler was found at KWWMA in 2007 based on the multi-agency census efforts ongoing in Michigan since the early 1970s (Probst et al. 2003). The majority of birds are relatively evenly distributed across the more extensive Michigan Department of Natural Resources and US Forest Service jack pine stands (unpublished data).

\section{Managing for Multiple Species at KWWMA}

Although most pre-European jack pine forests were established following stand-replacing fires, changes to land use, the increased density of rural homes, and the demand for forest products limits the feasibility of broad-scale use of prescribed fire as a method for regenerating jack pine in much of the northern Lower Peninsula of Michigan. Forest management instead has focused on clearcutting jack pine stands and replanting 2-year old jack pine seedlings at high densities in an opposing wave pattern, whereby dense patches of jack pine are separated by small $(<1$ ha $[<1$ ac. $])$ openings (Fig. 5). These small openings are intended to emulate the heterogeneous forest landscape structure expected to result from frequent stand-replacing fires. Multi-agency efforts to manage jack pine habitat have led to a population increase and a range expansion of Kirtland's warbler (Probst et al. 2003, Donner et al. 2008). However, the relatively homogenous composition and structure of managed stands do not emulate those resulting from wildfire (Goebel et al. 2007), and such intensive management may not bode well for long-term ecological sus- tainability (Holling and Meffe 1996). Consequently, with the population of Kirtland's warbler at or above established recovery objectives since 2001, research and management at KWWMA has focused on multi-species conservation scenarios from habitat management and enhancing stand structures.

Recent research indicates that the 3 successional stages of managed jack pine (i.e., recent clearcut, young (5- to 23 -yearold) jack pine, and mature ( $>23$-year-old) stands) have suites of bird species strongly associated with each stage (Goebel et al. 2007. Although overall bird diversity increases with stand age and structural complexity, each stage is populated by species of significant conservation priority based on Partners in Flight Conservation Scores (Carter et al. 2000) or the U.S. Fish and Wildlife Service, Midwest Region (USFWS 2002). For instance, in recently clearcut jack pine stands, conditions that in many respects emulate the regionally rare jack pine barrens ecosystem are inhabited by bird species such as upland sandpiper (Bartramia longicauda Bechstein) and other species of flora and fauna considered grassland or openland obligates. Along with Kirtland's Warbler, dense stands of young jack pine are also inhabited by black-billed cuckoo (Coccyzus erythropthalmus Wilson) and other shrubland bird species. And mature jack pine, with its greater structural complexity, is used by rose-breasted grosbeaks (Pheucticus ludovicianus $\mathrm{L}$.) and many other forest interior bird species.

\section{Biological Legacies at KWWMA}

Research has also been initiated to quantify the value of retaining and creating biological legacies, i.e., coarse woody debris and snags. For example, in 2007, loggers used processor heads to girdle live trees to produce snags, while maintaining as many existing natural snags as possible in 2007, in a 35-ha (86-ac) stand of jack pine. Because larger snags provide a broader range of ecological and wildlife habitat benefits than smaller ones (Fan et al. 2003) and because they tend to last longer (Conner and Saenz 2005), all the managed snags were at or above the mean diameter of the live trees in the stand $23 \mathrm{~cm}$ (9 in) DBH. An estimated total of 1000 snags (both natural and managed) comprised the residual structure post-harvest. Subsequently, 336 snags were inventoried, with an almost even split of natural and managed snags. Approximately half of all inventoried snags, natural or managed, were jack pine, with the majority of the other snags oak (Quercus spp.). Within 1 year, only $13 \%$ of natural snags had fallen, compared to $28 \%$ of all managed snags, suggesting the importance of maintaining existing snags as they may have greater stability against the wind. Monitoring and analysis of these data are ongoing and results should provide comparable finding with similar studies conducted in other forest ecosystems (Shea et al. 2002). Ultimately, the future of jack pine ecosystem management for Kirtland's warbler may rest in a broadscale, ecological approach to ecosystem management, rather than solely based on intensive habitat management.

\section{Conclusions}

Limitations to applying ecological forest management techniques to the National Wildlife Refuge System include those common to most land management agencies: altered fire regimes, invasive species, single-species management myopia, fragmented ownerships, and unwillingness by some 
to manage late-successional ecosystems. Nonetheless, active management driven by a consideration of reference conditions and ecological patterns and processes may help to meet congressional mandates, and achieve ecosystem and wildlife habitat goals and objectives. Forest ecosystems within the NWRS will continue to serve as an excellent crucible to apply and evaluate the principles of ecological forestry.

\section{Acknowledgements}

The findings and conclusions in this article are those of the authors and do not neccessarily reflect the views of the US Fish and Wildlife Service. The authors thank the present staff of Seney National Wildlife Refuge for their review of this manuscript, especially Dave Olson (Biologist) and Gary Lindsay (Fire Management Officer). Heather Shaw (Central Michigan University) assisted with data collection. We would also like to acknowledge Chris Burnett, Jack Culpepper, Jeff Denman, Chuck Hunter, Carl Schmidt and Mike Tansy for stimulating some of the work described herein.

\section{References}

Askins, R.A. 2000. Restoring North America's birds: lessons from landscape ecology. Yale University Press, New Haven, CT. 320 p.

Bergeron, Y. and J. Brisson. 1990. Fire regime in red pine stands at the northern limit of the species range. Ecology 71: 1352-1364.

Burger, T.L. and J. Kotar. 2003. A guide to forest communities and habitat types of Michigan. University of Wisconsin Press, Madison, WI. 400 p.

Carter, F.C., W.C. Hunter, D.N. Pashley and K.V. Rosenberg. 2000. Setting conservation priorities for landbirds in the United States: the Partners in Flight approach. Auk 117: 541-548.

Comer, P.J., D.A. Albert, H.A. Wells, B.L. Hart, J.B. Raab, D.L. Price, D.M. Kashian, R.A. Corner and D.W. Schuen. 1995. Michigan's native landscape. Michigan Natural Features Inventory, Lansing, MI. 76 p.

Conner, R.N. and D. Saenz. 2005. The longevity of large pine snags in eastern Texas. Wildlife Society Bulletin 33: 700-705.

Crozier, G.E. and G.J. Niemi. 2003. Using patch and landscape variables to model bird abundance in a naturally heterogeneous landscape. Canadian Journal of Zoology 81: 441-452.

Dickman, D.I. and L.A. Leefers. 2003. The forests of Michigan. University of Michigan Press, Ann Arbor, MI. 304 p.

Donner, D.M., J.R. Probst and C.A. Ribic. 2008. Influence of habitat amount, arrangement, and use on population trend estimates of male Kirtland's warblers. Landscape Ecology 23: 467-480.

Drobyshev, I., P.C Goebel, D.M. Hix, R.G. Corace, III and M. Semko-Duncan. 2008a. Pre- and post-European settlement fire history of red pine-dominated forest ecosystems of Seney National Wildlife Refuge, Upper Michigan. Canadian Journal of Forest Research 38: 2497-2514.

Drobyshev, I., P.C Goebel, D.M. Hix, R.G. Corace, III and M. Semko-Duncan. 2008b. Interactions between forest composition, structure, fuel loadings and fire history: a case study of red pinedominated forests of Seney National Wildlife Refuge. Forest Ecology and Management 256: 1723-1733.

Fan, Z., S.R. Shifley, M.A. Spetich, F.R. Thompson, III and D.R. Larsen. 2003. Distribution of cavity trees in Midwestern old-growth and second-growth forests. Canadian Journal of Forest Research 33: 1481-1494.

Forman, R.T.T. 1995. Land mosaics: the ecology of landscapes and regions. Cambridge University Press, Cambridge, UK. 632 p.

Franklin, J.F., R.J. Mitchell and B.J. Palik. 2007. Natural disturbance and stand development principles for ecological forestry. USDA For. Serv. Gen. Tech. Rep. NRS-GTR-19. 44 p.

Frelich, L.E. 2002. Forest dynamics and disturbance regimes. Cambridge University Press, Cambridge, UK. 266 p.
Fule, P.Z., A.E.M. Waltz, W.W. Covington and T.A. Heinlein. 2001. Measuring forest restoration effectiveness in reducing hazardous fuels. Journal of Forestry 99: 24-24.

Goebel, P.C., D.L. McCormick and R.G. Corace, III. 2007. Ecological assessment of the USDI Fish and Wildlife Service's Kirtland's Warbler Wildlife Management Area. The School of Environment and Natural Resources, Ohio Agricultural Research and Development Center, The Ohio State University, Columbus, OH. 72 p.

Harrington, E. 2006. Small mammals, habitat, and forest restoration at Seney National Wildlife Refuge. M. Sc. Thesis, Univ. of Michigan, Ann Arbor, MI. 29 p.

Heinselman, M.L. 1965. String bogs and other patterned organic terrain near Seney, Upper Michigan. Ecology 46: 185-188.

Heinselman, M.L. 1973. Fire in the virgin forests of the Boundary Waters Canoe Area, Minnesota. Quaternary Research 3: 329-382.

Holling, C.S. and G.K. Meffe. 1996. Command and control and the pathology of natural resource management. Conservation Biology 10: $328-337$.

Hunter, M.L., Jr. 1990. Wildlife, forests, and forestry. Prentice-Hall, Inc., Englewood Cliffs, NJ. 370 p.

Johnson, C.S. 1947. Canada goose management, Seney National Wildlife Refuge. Journal of Wildlife Management 11: 21-24.

Karamanski, T.J. 1989. Deep woods frontier: a history of logging in northern Michigan. Wayne State University Press, Detroit, MI. 305 p. Karr, J.R. 2004. Beyond definitions: maintaining biological integrity, diversity, and environmental health in National Wildlife Refuges. Natural Resource Journal 44: 1067-1092.

Losey, E.B. 2003. Seney National Wildlife Refuge: its history. Lake Superior Press, Marquette, MI. 72 p.

Lovett, G.M, C.D. Canham, M.A. Arthur, K.C. Weathers and R.D. Fitzhugh. 2006. Forest ecosystem responses to exotic pests and pathogens in eastern North America. BioScience 56: 395-405.

Meretsky, V.J., R.L. Fischman, J.R. Karr, D.A. Ashe, J.M. Scott, R.F. Noss and R.L. Schroeder. 2006. New directions in conservation for the National Wildlife Refuge System. BioScience 56: 135-143.

Ostrofsky, W.D. and M.L. McCormack, Jr. 1986. Silvicultural management of beech and beech bark disease. Northern Journal of Applied Forestry 3: 89-91.

Perkey, A.W. and B.L. Wilkins. 2001. Crop tree field guide. USDA For. Serv. Northeastern Area NA-TP-10-01. 97 p.

Probst, J.R. 1986. A review of factors limiting the Kirtland's Warbler on its breeding grounds. American Midland Naturalist 116: 87-100. Probst, J.R., D. Donner, C.I. Bocetti and S. Sjogren. 2003. Population increase in Kirtland's warbler and summer range expansion to Wisconsin and Michigan's Upper Peninsula, USA. Oryx 37: 365-373. Rist, S. 2008. Legacies of forest management and fire in mixed-pine forest ecosystems of the Seney National Wildlife Refuge, eastern Upper Michigan. M. Sc. Thesis, The Ohio State Univ., Columbus, OH. 90 p.

Sallabanks, R. and E.B. Arnett. 2005. Accommodating birds in managed forests in North America: a review of bird-forestry relationships. In C.J. Ralph and T.D. Rich (eds.). Bird conservation implementation and integration in the Americas: proceedings of the third international Partners in Flight Conference. pp. 345-365. USDA For. Serv. Gen. Tech. Rep. PSW-GTR-191. 643 p.

Schroeder, R.L., J.I. Holler and J.P. Taylor. 2004. Managing National Wildlife Refuges for historic and non-historic conditions: determining the role of the refuge in the ecosystem. Natural Resource Journal 44: 1185-1210.

Scott, J.M., T. Loveland, R. Gergely, J. Strittholt and N. Staus. 2004. National Wildlife Refuge System: ecological context and integrity. Natural Resource Journal 44: 1041-1066.

Seymour, R.S. and M.L. Hunter, Jr. 1999. Principles of ecological forestry. In M.L. Hunter, Jr. (ed.). Managing biodiversity in forest ecosystems. pp. 22-61. Cambridge University Press, Cambridge, UK. 714 p.

Shea, P.J., W.F. Laudenslayer, Jr., F. Ferrell and R. Borys. 2002. Girdled versus bark beetle-created ponderosa pine snags: utilization by 
cavity-dependent species and differences in decay rate and insect diversity. pp. 145-153. USDA For. Serv. Gen. Tech. Rep. PSW-GTR-181. Simberloff, D. 1997. Flagships, umbrellas, and keystones: is singlespecies management passé in the landscape era. Biol. Conserv. 83: 247-257.

[USFWS] U.S. Fish and Wildlife Service. 2002. Fish and Wildlife Resources Conservation Priorities-Region 3 (v. 2.0). U.S. Fish and Wildlife Service, Washington DC. Available at http://library.fws.gov/ pubs3/priorities02.pdf.
2006. Managing the forest and the trees: a forest management workshop for National Wildlife Refuges. Biological Monitoring Team, Region 3 and Region 5, Milton, DE.

Verme, L.J. 1996. Hiawatha's brothers: a wildlife retrospective. Avanti Publishing, Munising, MI. 143 p.

Zhang, Q., K.S. Pregitzer and D.D. Reed. 2000. Historical changes in the forests of the Luce District of the Upper Peninsula of Michigan. American Midland Naturalist 143: 94-110. 